Bangl. J. Vet. Med. (2008). 6 (1): 103-106

\title{
COMPARATIVE EFFICACY OF ANALGESIC AND ANAESTHETIC DRUGS FOR HIGH EPIDURAL ANALGESIA IN BLACK BENGAL GOATS
}

\author{
R. A. Runa, M. A. Hashim, M. A. Hossain, A. A. M. Bhuyan and M. S. Alam ${ }^{1}$
}

Department of Surgery and Obstetrics, Faculty of Veterinary Science, Bangladesh Agricultural University, Mymensingh-2202, Bangladesh, ${ }^{1}$ Holy Family Red Crescent Hospital, Dhaka, Bangladesh

\begin{abstract}
The effects of analgesic and anaesthetic drugs on high epidural analgesia in Black Bengal goats were investigated. The animals were divided into five groups $(n=8)$ and a replication of 8 trials was performed in each group at least one week interval. Two percent (2\%) lidocaine hydrochloride, $0.5 \%$ bupivacaine hydrochloride, $2 \%$ lidocaine hydrochloride with adrenaline, ketamine hydrochloride and diazepam were administered into lumbo-sacral (high epidural) space for high epidural analgesia. Bupivacaine hydrochloride significantly $(\mathrm{P}<0.05)$ decreased respiration rates, rectal temperature, however, increased heart rates during high epidural analgesia with prolonged analgesia compared to other drugs. Lidocaine hydrochloride showed a rapid onset and excellent analgesia and did not produce any side effects whereas, diazepam exhibited delay onset with short duration of analgesia. It seems that $2 \%$ lidocaine hydrochloride is effective for high epidural analgesia in goats.
\end{abstract}

Key words: Analgesics, anaesthetics, high epidural analgesia, goats

\section{INTRODUCTION}

Epidural analgesia, a regional analgesia, is needed to perform major surgical operations for correction of goat diseases as well local and regional analgesia have long being practiced for minor and major surgical affections. Among different types of local and regional analgesia, epidural analgesia technique is representing as an alternative to general analgesia for the patients at high risk. It has also been used in veterinary practice for diagnosis and treatment of obstetrical and surgical procedures at the caudal aspect of body; lower abdomen, flank, perennial region and in tail. Lidocaine has a relatively rapid onset and duration of action about 1 to 2 hours (Carpenter et al., 2004), however, bupivacaine is most commonly used for epidural nerve block (Eugene and Nicholas, 1995). Addition of adrenaline is a common practice for prolongation of the action of local analgesic drugs. Ketamine hydrochloride $(\mathrm{HCl})$, a disssociative agent has been used epidurally to relieve pre and post operative pain in both man and animals (Brander et al., 1991). Diazepam, a sedative agent has been used routinely for sedation in animals, though there is lack of evidence of its effects during high epidural analgesia. The present experiment was carried out to find out the analgesic effects of different analgesic and anaesthetic drugs during high epidural analgesia.

\section{MATERIALS AND METHODS}

A total of 8 (3 castrated males and 5 non pregnant females) goats were taken for the experiment in the operation theatre of the Department of Surgery and Obstetrics, Faculty of Veterinary Science and Veterinary Clinic, Bangladesh Agricultural University (BAU), Mymensingh. The body weight of these animals ranged from 7 to $10 \mathrm{~kg}$ and age ranged from 8 to 15 months. They were allowed to graze in the open field for 5 to 6 hours daily and water ad libitum. The animals were restrained on the operation table in right lateral recumbency. The site of injection was clipped, cleaned and disinfected and analgesic solution was inserted at the lumbo-sacral space. The animals were divided into 5 (five) different groups and a replication of 8 trails were performed in each group at one week interval. Two percent (2\%) lidocaine hydrochloride (Jasocaine ${ }^{\circledR}$, Jayson Pharmaceuticals Ltd.) 3ml, 0.5\% bupivacaine hydrochloride (Ultracaine ${ }^{\circledR}$, Jayson Pharmaceuticals Ltd.) 3ml, 2\% lidocaine hydrochloride with adrenaline (Jasocaine $A^{\circledR}$, Jayson Pharmaceuticals Ltd.) 3ml, ketamine hydrochloride (Calypsol $^{\circledR}$, Gedeon Richter Ltd., Budapest, Hungary) 1ml and diazepam (Sedil ${ }^{\circledR}$, Square Pharmaceuticals Ltd.) $2 \mathrm{ml}$ were injected into lumbo-sacral space in groups A, B, C, D and E respectively. 
Respiration rate, heart rate and rectal temperature were recorded before, during and after recovery of analgesia. The state of analgesia was determined by needle pricking in the lumbar region in every 5 minutes. Analgesia was assessed as “+++” (no response), “++” (slight movement or reflex response), “+” (avoidance response) by scoring excellent, adequate and poor respectively. Onset, peak point and the duration of analgesia were recorded and measured by a scale. Tail movement, leg movement and any side effects were closely observed and recorded during the course of analgesia. The data were analyzed statistically by Students' Paired " $t$ " test and ANOVA in completely randomized design.

\section{RESULTS AND DISCUSSION}

The effect of various analgesic and anaesthetic drugs on respiration rate, heart rate and rectal temperature in different groups of Black Bengal goats in high epidural analgesia are presented in Table 1.

Table1. Effects of analgesic and anaesthetic drugs on respiration rate, heart rate and rectal temperature during high epidural analgesia in Black Bengal goats

\begin{tabular}{|c|c|c|c|c|}
\hline Drugs used & $\begin{array}{l}\text { Time of recording } \\
\text { analgesia (interval } \\
=10 \mathrm{mins} \text { ) }\end{array}$ & $\begin{array}{l}\text { Respiratory } \\
\text { rate }(\min )^{\mathrm{a}}\end{array}$ & $\begin{array}{l}\text { Heart rate } \\
(\min )^{\mathrm{a}}\end{array}$ & $\begin{array}{l}\text { Rectal } \\
\text { temperature }^{\mathrm{a}} \\
\left({ }^{0} \mathrm{~F}\right)\end{array}$ \\
\hline 2\% lidocaine HCL & $\begin{array}{l}\text { Before } \\
\text { During } \\
\text { After }\end{array}$ & $\begin{array}{l}32.50 \pm 5.53 \\
30.50 \pm 7.76 \\
33.13 \pm 6.17\end{array}$ & $\begin{array}{l}61.25 \pm 5.01 \\
65.25 \pm 8.00 \\
62.38 \pm 4.60\end{array}$ & $\begin{array}{l}102.71 \pm 0.67 \\
102.25 \pm 0.96 * * \\
102.38 \pm 0.44\end{array}$ \\
\hline 0.5\% bupivacaine HCL & $\begin{array}{l}\text { Before } \\
\text { During } \\
\text { After }\end{array}$ & $\begin{array}{l}31.75 \pm 6.54 \\
28.00 \pm 4.28 * \\
31.25 \pm 4.65\end{array}$ & $\begin{array}{l}63.25 \pm 8.21 \\
67.75 \pm 10.71 * \\
65.00 \pm 8.21\end{array}$ & $\begin{array}{l}102.38 \pm 1.24 \\
102.09 \pm 1.32 * \\
101.96 \pm 1.55\end{array}$ \\
\hline $\begin{array}{l}\text { 2\% lidocaine HCL } \\
\text { with adrenaline }\end{array}$ & $\begin{array}{l}\text { Before } \\
\text { During } \\
\text { After }\end{array}$ & $\begin{array}{l}32.25 \pm 4.83 \\
28.00 \pm 3.85 * * \\
32.25 \pm 4.17\end{array}$ & $\begin{array}{l}66.25 \pm 5.50 \\
68.00 \pm 9.07 \\
66.50 \pm 6.21\end{array}$ & $\begin{array}{l}101.95 \pm 0.99 \\
101.61 \pm 1.15^{*} \\
101.63 \pm 1.62\end{array}$ \\
\hline Ketamine HCL & $\begin{array}{l}\text { Before } \\
\text { During } \\
\text { After }\end{array}$ & $\begin{array}{l}31.50 \pm 4.11 \\
35.00 \pm 10.25 \\
32.25 \pm 4.20\end{array}$ & $\begin{array}{l}57.75 \pm 8.24 \\
64.25 \pm 7.21^{* *} \\
60.75 \pm 7.25\end{array}$ & $\begin{array}{l}103.18 \pm 1.09 \\
102.43 \pm 0.82^{* *} \\
102.43 \pm 0.66^{*}\end{array}$ \\
\hline Diazepam & $\begin{array}{l}\text { Before } \\
\text { During } \\
\text { After }\end{array}$ & $\begin{array}{l}33.00 \pm 7.41 \\
30.25 \pm 7.74 * \\
32.13 \pm 7.64\end{array}$ & $\begin{array}{l}62.00 \pm 6.14 \\
66.25 \pm 5.39 * * \\
63.50 \pm 5.42\end{array}$ & $\begin{array}{l}102.28 \pm 0.80 \\
102.11 \pm 0.75 \\
102.03 \pm 0.72\end{array}$ \\
\hline
\end{tabular}

${ }^{\mathrm{a}}$ Mean $\pm \mathrm{SD}, *=$ Significant $(\mathrm{P}<0.05)$, ** = Highly significant $(\mathrm{P}<0.01)$.

Two percent (2\%) lidocaine hydrochloride insignificantly decreased respiration rates and increased heart rates in all the experimental animals. Bupivacaine hydrochloride $(0.5 \%)$ significantly $(\mathrm{P}<0.05)$ decreased respiration rates and rectal temperature. Singh et al. (2005) also found significant fall in respiration rate after epidural administration of medetomidine or bupivacaine in goats. Decreased respiratory rate might result from their depressing action on respiratory center in central nervous system (Hall and Clarke, 1989). When 2\% lidocaine hydrochloride with adrenaline was used respiration rates significantly $(\mathrm{P}<0.01)$ decreased and heart rates insignificantly increased. Ketamine hydrochloride increased heart rates significantly $(\mathrm{P}<0.01)$ but respiration rates insignificantly. This result corresponds with the study reported by Singh et al. (2002). The initial bradycardia followed by increase in heart rate might be due to cardiovascular stimulant effect of ketamine (Kumar and Singh, 1990). Diazepam decreased respiration rates significantly $(\mathrm{P}<0.05)$ whereas increased heart rate significantly $(\mathrm{P}<0.01)$. Sanhouri et al. (1991) reported the similar suppressive effect on respiration in goat by diazepam injected through lumbo-sacral space. This reduction in respiration rate resulted from direct depressing effect of diazepam on central nervous system. In this study, temperature in goats of most of the groups decreased. There is no report on the effect of local analgesic agents on body temperature during epidural analgesia in goats. 
The analgesic effects were assessed in different goats by using scoring method. Two percent (2\%) lidocaine hydrochloride produced excellent analgesia compared to other drugs. There were significant differences in different variance after epidural injection of same drug with same dose in different goats (Table 2). The onset was rapid in case of $2 \%$ lidocaine hydrochloride. On the contrary, the onset was slower in case of $0.5 \%$ bupivacaine hydrochloride and diazepam. Mahale and Wakanker (1992) observed the similar findings in goat. There was no report about onset of analgesia after epidural administration of diazepam in goats.

Table 2. Effects of analgesic and anaesthetic drugs during high epidural analgesia in Black Bengal goats

\begin{tabular}{|lllll|}
\hline Drugs used & $\begin{array}{l}\text { Onset of } \\
\text { analgesia (min) }\end{array}$ & $\begin{array}{l}\text { Peak point of } \\
\text { analgesia (min) }\end{array}$ & $\begin{array}{l}\text { Desensitized } \\
\text { area (cm) }\end{array}$ & Duration (min) \\
\hline 2\% lidocaine HCL & $1.88 \pm 0.64^{\mathrm{c}}$ & $15.50 \pm 4.04^{\mathrm{a}}$ & $22.63 \pm 9.00^{\mathrm{a}}$ & $63.50 \pm 14.91^{\mathrm{a}}$ \\
$0.5 \%$ bupivacaine HCL & $5.13 \pm 2.10^{\mathrm{b}}$ & $15.00 \pm 3.63^{\mathrm{a}}$ & $25.21 \pm 10.30^{\mathrm{a}}$ & $81.75 \pm 36.64^{\mathrm{a}}$ \\
2\% lidocaine HCL with & $4.88 \pm 1.73^{\mathrm{b}}$ & $11.25 \pm 3.85^{\mathrm{ab}}$ & $21.81 \pm 7.73^{\mathrm{a}}$ & $81.50 \pm 23.14^{\mathrm{a}}$ \\
adrenaline & & & & \\
Ketamine HCL & $5.00 \pm 1.60^{\mathrm{b}}$ & $8.38 \pm 2.50^{\mathrm{b}}$ & $18.18 \pm 10.55^{\mathrm{a}}$ & $27.63 \pm 7.63^{\mathrm{b}}$ \\
Diazepam & $7.88 \pm 1.36^{\mathrm{a}}$ & $10.38 \pm 1.69^{\mathrm{b}}$ & $18.88 \pm 7.09^{\mathrm{a}}$ & $25.50 \pm 7.03^{\mathrm{b}}$ \\
\hline
\end{tabular}

Values with different superscript letters in the same column differ significantly $(\mathrm{P}<0.01)$.

The high peak time of analgesia was found with $2 \%$ lidocaine hydrochloride among different local analgesic agents. This observation corresponds with the previous findings (DeRossi, 2005). The inherent spreading power of lidocaine might be responsible for its wider spread blockade and intense action (Hall and Clarke, 1989). The duration of analgesia with $0.5 \%$ bupivacaine hydrochloride was found longer than $2 \%$ lignocaine hydrochloride in this experiment. The protein binding characteristics of local analgesic agents influence the duration of action (Gissen et al., 1980). Lidocaine showed intermediate duration of action among other agents used here. This observation was supported by Lemke and Dawson (2000). The duration of analgesia with diazepam was very short among all the groups of the experiment. Drowsiness and shivering were found during epidural analgesia with $0.5 \%$ bupivacaine hydrochloride. These findings are in agreement with the study reported by Laishley et al. (1988). In case of diazepam more drowsiness and salivation were observed in all the animals. It is suggested that $2 \%$ lidocaine hydrochloride is the effective analgesic agent for high epidural analgesia comparing to other agents.

\section{REFERENCES}

1. Brander GG, Pugh DM, Bywater RJ and Jenkins WL (1991). Veterinary Applied Pharmacology and Therapeutics. $5^{\text {th }}$ edn., ISBN, Bailliere Tindal, London. pp. 110-114.

2. Carpenter RE, Wilson DV and Evans AT (2004). Evaluation of intraperitoneal and incisional lidocaine or bupivacaine or analgesia following ovarihysterectomy in the dog. Anaesthesia and Analgesia 31: 46-52.

3. DeRossi R, Junqueira AL and Beretta MP (2005). Analgesic and systemic effects of xylazine, lidocaine and their combination after subarachnoid administration in goats. Journal of South African Veterinary Association 76 (2): 79-84.

4. Eugene PS and Nicholas HB (1995). Local anaesthetics. In: Veterinary Pharmacology and Therapeutics. Iowa State University Press. pp. 271-358.

5. Gissen AJ, Covino BG and Gregvs J (1980). Differential sensitivity of mammalian nerve fibres to anaesthetic agents. Anaesthesiology 53: 467-474.

6. Hall LW and Clarke KW (1989). Veterinary Anaesthesia. $8^{\text {th }}$ edn., Bailiere Tindal, London. pp. 240-242.

7. Kumar A and Singh H (1990). Clinical and physiological effects of ketamine with and without diazepam or meperidine premedication in dog. Indian Veterinary Journal 67 (3): 242-246.

8. Laishley RS, Morgan BM and Reynolds F (1988). Effect of bupivacaine on extradural anaesthesia. British Journal of Anaesthesia 60: 180-186.

9. Lemke KA and Dawson SD (2000). Local and regional anesthesia. Veterinary Clinic of North American Small Animal Practice 30 (4): 839-857. 
10. Mahale AR and Wakankar CC (1992). Comparative evaluation of different techniques of regional analgesia of the udder in goat. Indian Journal of Veterinary Surgery 14 (1): 21-22.

11. Sanhouri AA, Jones RS and Dobson H (1991). Preliminary results on the effects of diazepam. British Veterinary Journal 147 (4): 388-398.

12. Singh V, Amarpal, Kinjavdekar P, Aithal HP and Pratap K (2005). Medetomidine with Ketamine and Bupivacaine for Epidural Analgesia in Buffaloes. Veterinary Research Communication 29 (1): 18.

13. Singh V, Kinjavdekar P, Pratap K and Aithal HP (2002). Epidural analgesia with medetomidine, ketamine along and in combination in buffaloes calves. Indian Journal of Veterinary Surgery 23 (1): 64. 